\title{
Ks. Tomasz Bajer, Katarzyna Dybeł, „Dobrze używałeś kapłaństwa, mój bracie...”. Księża Stanisław i Andrzej Bajerowie: świadectwo życia, świadectwo epoki, Kraków 2011, 374 s.
}

Książka ks. dra Tomasza Bajera i prof. Katarzyny Dybeł stanowi ciekawą, nowatorską i interdyscyplinarną próbę przedstawienia wybranych aspektów historii Kościoła krakowskiego w dramatycznym okresie II wojny światowej, a następnie PRL-u (do roku 1977). Dzieje te ukazane zostają przez pryzmat działalności księży Stanisława i Andrzeja Bajerów - braci, których świadectwo życia i kapłaństwa stało się czytelnym drogowskazem dla wielu współczesnych im ludzi, poddanych eksperymentowi podwójnego totalitaryzmu. Pierwszy z nich, ks. Stanisław Bajer (1907-1945), wybitny kaznodzieja i duszpasterz, pełnił w latach 1942-1945 posługę administratora w parafii Wniebowzięcia Najświętszej Maryi Panny w Oświęcimiu, na terenie której znajdował się nazistowski Konzentrationslager. Pracując w ekstremalnie trudnych warunkach, o których świadczy m.in. zachowana korespondencja z księciem arcybiskupem Adamem Sapiehą, niósł potajemnie duchową i materialną pomoc więźniom i uciekinierom. Mianowany po wojnie proboszczem w parafii św. Małgorzaty i Katarzyny w Kętach, a następnie w parafii św. Wojciecha i Katarzyny w Jaworznie i w parafii Wszystkich Świętych w Krakowie, kontynuował swą posługę, stając się oparciem dla wszystkich, wśród których przyszło mu żyć. Ks. Andrzej Bajer (1909-1977) - po krótkim pobycie w Morawicy i Więcławicach - związał swe życie z parafią Pana Jezusa Dobrego Pasterza na Prądniku Czerwonym w Krakowie, gdzie - nie ulegając namowom do współpracy i prześladowaniom - budował nową światynię.

Byłoby zbytnim uproszczeniem przedstawiać recenzowaną pozycję jako biografię dwóch nieprzeciętnych kapłanów. Wpisuje się ona także w nurt teologii duchowości, historii Kościoła i Małopolski oraz badań filologicznych w tym szczególnym obszarze, jakim jest pochylenie się nad słowem ludzkim i Słowem Objawionym, stanowiące integralną część misji każdego teologa i kapłana. Ta wielopoziomowość badań wydaje sięjednym z najcenniejszych atutów monografii.

Dokumenty, do jakich sięgnęli autorzy, sytuują się na różnych płaszczyznach: archiwum Kurii metropolitalnej w Krakowie, parafialne kroniki, homilie, korespondencja, dzienniki, zapiski, wspomnienia i relacje. Nie pominęli też archiwów IPN w Wieliczce, które dostarczyły nieznanych dotąd nikomu (poza komunistycznymi służbami bezpieczeństwa) informacji, odsłaniających mechanizmy prześladowania Kościoła katolickiego w Polsce. Źródła te uzupełniają 
się nawzajem, dając w efekcie bogaty i spójny obraz, inspirujący do dalszych badań i refleksji.

Książka, do której przedmowę napisał kard. Stanisław Dziwisz, składa się z czterech obszernych rozdziałów, opatrzonych wstępem, konkluzją, bibliografią tekstów źródłowych i opracowań krytycznych, indeksem osób i nazw geograficznych oraz streszczeniem w języku francuskim.

Układ całości odznacza się logiką i przejrzystością. Wychodząc z założenia, że człowiek rodzi sięi realizuje w określonej czasoprzestrzeni, autorzy prowadzą czytelnika drogą, jaką przemierzyli księża Bajerowie, sięgając aż do korzeni i wskazując, jak istotną rolę w formowaniu ich powołania odegrało środowisko rodzinne i szkolne. Nie jest to samotne wędrowanie; na drodze tej pojawiają się ludzie wybitni, świeccy i duchowni, których Boża Opatrzność postawiła na drodze księży Bajerów: wśród nich bł. ks. Piotr Dańkowski, najbliższy przyjaciel ks. Stanisława Bajera i inni koledzy rocznikowi - m.in. sługa Boży ks. Michał Rapacz i sługa Boży ks. Władysław Bukowiński. Także tym postaciom autorzy poświęcają wiele uwagi, uzupełniając przez to obraz polskiego Kościoła niespokojnych czasów. Książka stanowi też skromny, lecz konkretny przyczynek do historii Wydziału Teologicznego Uniwersytetu Jagiellońskiego oraz Arcybiskupiego Seminarium Duchownego w Krakowie. Na podstawie zachowanych dokumentów (zapiski ks. Bajerów, zachowany indeks) można poszerzyć wiedzę o tym, jak w okresie międzywojennym wyglądało życie codzienne krakowskiego żaka-seminarzysty i realizowany przez niego program nauczania.

Kolejne rozdziały - zredagowane w sposób uporządkowany i metodologicznie poprawny - poświęcone zostały działalności duszpasterskiej najpierw ks. Stanisława, a następnie ks. Andrzeja. Wyłania się z nich obraz osobowości silnych, wewnętrznie spójnych, przyciągających i przemieniających, skłaniający do refleksji nad sekretem tak skutecznej posługi pomimo niesprzyjających czasów. Częścią tego sekretu było z pewnością mocne zakorzenienie w Chrystusie, bezgraniczny i radosny dar z siebie oraz spójność życia z głoszonym nauczaniem.
Monografię dopełnia aneks, na który składa się kalendarium życia księży Bajerów, ich nauki i homilie oraz świadectwa i wspomnienia osób, które znały księży Bajerów, w tym śp. biskupa Albina Małysiaka. Autorzy zdecydowali się też umieścić homilie wygłoszone przez kardynała Karola Wojtyłę na pogrzebie księży Stanisława i Andrzeja Bajerów, niezwykle trafnie charakteryzujące ich osoby i działalność. To właśnie słowa zawarte w jednej z tych homilii stały się mottem umieszczonym w tytule recenzowanej pozycji. Przygotowanie wspomnianego aneksu było pracochłonnym, ale i trafnym pomysłem: znalazły się tu nie tylko cenny materiał do badań homiletycznych Kościoła okresu okołowojennego i dokumentacja przybliżająca dzieje tego Kościoła poprzez pryzmat wspomnień mocno osadzonych w realiach epoki, ale też mało znane teksty Karola Wojtyły, niezwykle istotne dla refleksji nad istotą i tożsamością kapłaństwa.

Warto podkreślić bogatą, trafnie dobraną, unikalną i starannie opisaną dokumentację fotograficzną, która dobrze uzupełnia namalowany słowami obraz epoki. Nie bez znaczenia jest też fakt, że książka, przy całej swej naukowości, napisana została językiem żywym, starannym i przystępnym, co znacznie poszerza krąg jej odbiorców i obala stereotyp, że pisać ładnie i prosto znaczy pisać nienaukowo.

Zdzisław J. Kijas OFMConv 